\title{
Production of a Renibacterium salmoninarum hemolysin fusion protein in Escherichia coli K12
}

\author{
Thomas H. Grayson, Andrew J. Evenden, Martyn L. Gilpin, Colin B. Munn*
}

Department of Biological Sciences, University of Plymouth, 6 Queen Anne Terrace, North Hill, Plymouth PL4 8AA, United Kingdom

\begin{abstract}
Gene rsh encoding a novel hemolysin of Renibacterium salmoninarum was fused to the lacZ gene of the pAX5+ plasmid vector to facilitate production of a $160 \mathrm{kDa} \beta$ galactosidase fusion protein. The soluble fusion protein was produced cytoplasmically in Escherichia coli XL1-Blue and purified using affinity chromatography. The fusion protein retained epitopes which were identified in components present in in vitro cultures of $R$. salmoninarum. Western blots of $R$. salmoninarum cell extracts which were probed with an antiserum raised against the affinity purified fusion protein predominantly recognized bands of apparent molecular weights 82 and $78 \mathrm{kDa}$ as well as a number of other bands which may represent breakdown products of the native protein. No components were detected in extracellular products and iron-restricted culture conditions did not obviously affect the production of these components
\end{abstract}

KEY WORDS: Renibacterium salmoninarum - Bacterial kidney disease $\cdot$ BKD $\cdot$ Hemolysin - Fusion protein

Renibacterium salmoninarum is an obligate pathogen of salmonid fish species worldwide (Evelyn 1993). This Gram-positive, intracellular bacterium is the etiologic agent of a chronic infection typified by granulomatous lesions within the host's kidney and referred to as bacterial kidney disease (BKD). BKD has proved to be a particularly difficult disease to control using either antibiotics or immunoprophylaxis. In addition, the bacterium is very slow growing, having a generation time of 24 to $48 \mathrm{~h}$, and many studies have been constrained by the lack of defined or minimal media. Consequently, little is known of the biochemistry, pathogenicity or virulence mechanisms of $R$. salmoninarum (Evenden et al. 1993).

The application of molecular methods to studies of many other bacterial pathogens has led to outstanding advances in our understanding of pathogenicity and

-Addressee for correspondence virulence mechanisms (Findlay 1993). Recently, some of these methods have been applied to the study of Renibacterium salmoninarum, and the genes encoding the major soluble antigen (msa) and a previously undescribed metalloprotease ( $h l y$ ) have been cloned and sequenced (Chien et al. 1992, Grayson et al. 1995a). Furthermore, Evenden et al. (1990) reported the cloning and expression of a gene from $R$. salmoninarum which encoded a hemolytic product that was not detected on Western blots probed with antisera raised against $R$. salmoninarum products derived from in vitro cultures of the bacterium. The gene, designated $r s h$, has subsequently been sequenced and found to encode a novel protein of unknown function (Evenden 1993).

The purpose of this study was to provide a source of this hemolytic protein which could be used for further research and which was not dependent upon timeconsuming and contamination-prone cultures of Renibacterium salmoninarum. A $\beta$-galactosidase fusion protein was produced in Escherichia coli and purified by affinity chromatography. Antiserum was raised against the purified fusion protein and used to probe Western blots of $R$. salmoninarum cell extracts and extracellular products (ECP). Because many pathogens produce components which are vital to pathogenesis when iron is no longer freely available (Bullen \& Griffiths 1987), cultures of $R$. salmoninarum were grown under iron-restricted and iron-sufficient conditions. Epitopes of the fusion protein were present in cell extracts but not ECP of 7 strains of $R$. salmoninarum, and restricting the availability of iron in vitro did not affect the expression of gene $r$ sh.

Materials and methods. Escherichia coli XL1-Blue was used as host strain and was cultured in LuriaBertani medium at $37^{\circ} \mathrm{C}$. When appropriate, $100 \mu \mathrm{g}$ $\mathrm{ml}^{-1}$ of ampicillin, $15 \mu \mathrm{g} \mathrm{ml^{-1 }}$ of tetracycline and $0.2 \% \mathrm{v} / \mathrm{v}$ glucose were added to the medium. Plas- 
mid expression vector $\mathrm{pAX} 5+(6.201 \mathrm{kbp})$ was used for the construction of the lacZ-rsh gene fusion (Markmeyer et al. 1990). Isolates of Renibacterium salmoninarum including the type strain (ATCC 33209) were cultured for $3 \mathrm{wk}$ in Mueller-Hinton medium supplemented with $0.1 \%$ L-cysteine hydrochloride (MHCB) at $15^{\circ} \mathrm{C}$. The availability of iron was restricted in cultures of $R$. salmoninarum by the addition of $200 \mu \mathrm{M}$ ethylenediamine dilo-hydroxyphenylacetic acid) (EDDHA) as previously described (Grayson et al. 1995b).

The cloning and sequencing of gene rsh encoding a hemolysin has been reported (Evenden 1993). On the basis of this information a translational fusion was constructed by ligating a $1.52 \mathrm{kbp}$ Eco47 III/Sall fragment to the NruI/Sall sites of the PAX5+polylinker (Fig. 1). The production of the soluble fusion protein in Escherichia coli was optimised over a time course following induction of the $l a c Z$ promoter with isopropyl $\beta$ D-thiogalactopyranoside (IPTG). All the following steps were carried out either on ice or at $4^{\circ} \mathrm{C}$ to minimise protein degradation. At $3 \mathrm{~h}$ post-induction, a sample of cells was removed, resuspended in column buffer $\left(20 \mathrm{mM}\right.$ Tris- $\mathrm{HCl}_{1} 10 \mathrm{mM} \mathrm{MgCl}, 0.5 \mathrm{M} \mathrm{NaCl}$, $10 \mathrm{mM} \beta$-mercaptoethanol, $1 \mathrm{mM} \mathrm{NaN}_{3}, 1 \mathrm{mM}$ PMSF, $\mathrm{pH}$ 7.4), frozen overnight at $-20^{\circ} \mathrm{C}$, thawed in cold water and sonicated. The samples were centrifuged and the supernatant (crude extract) removed and retained. Samples of uninduced cells, induced cells (1, 2, 3 and $4 \mathrm{~h}$ post-induction), crude extract, insoluble material and soluble material bound by the affinity resin were all analyzed by SDS-PAGE and Western blotting for the presence of fusion protein. Pure $\beta$-galactosidase fusion protein was isolated using a column of $p$-aminophenyl $\beta$-D-thiogalactopyranoside (APTG) agarose resin. The crude extract, isolated as described above, was retained on ice and diluted 1:5 with column buffer. The pellet of insoluble matter was resuspended in a minimum volume of column buffer, sonicated, and pelleted as before and this supernatant was added to the first crude extract. The affinity resin was washed with column buffer and the diluted crude extract containing the $\beta$-galactosidase fusion protein was loaded onto the column and subsequently, the column was washed free of all protein other than the specifically bound fusion protein. The fusion protein was eluted with $0.1 \mathrm{M}$ boric acid, $\mathrm{pH} 10.0$, and fractions were pooled and mixed with an equal volume of $1 \mathrm{M}$ Tris- $\mathrm{HCl} \mathrm{pH} 7.0$ in order to adjust the eluate to neutral $\mathrm{pH}$.

Wistar rats were injected subcutaneously with $100 \mu$ of the fusion protein emulsified in Freuind's complete adjuvant (FCA), boosted 3 wk later with $100 \mu \mathrm{g}$ of fusion protein emulsified in Freund's incomplete adjuvant ( $F_{\text {.A }}$ ), and then bled $3 \mathrm{wk}$ after the last injection. Control sera were gathered prior to immunisation. Following SDS-PAGE (Laemmli 1970), bacterial proteins were either stained for protein using Coomassie Brilliant Blue R250 or transferred electrophoretically onto nitrocellulose (Towbin et al. 1979) and probed with either the IgG fraction of mouse anti- $\beta$-galactosidase antiserum (Sigma) at 1:1000 dilution followed by goat anti-mouse IgG peroxidase conjugate at 1:2000 (Dako) or rat anti$\beta$-galactosidase fusion protein (1:200) followed by rabbit anti-rat IgG peroxidase conjugate at 1:1000 (Dako). Specific binding was visualised by immunoperoxidase staining.

Results and discussion. A recombinant plasmid, designated pGHLY, containing an in-frame fusion between lacZ and rsh was constructed using the pAX5+ expression vector (Fig. 2). Preliminary experi-

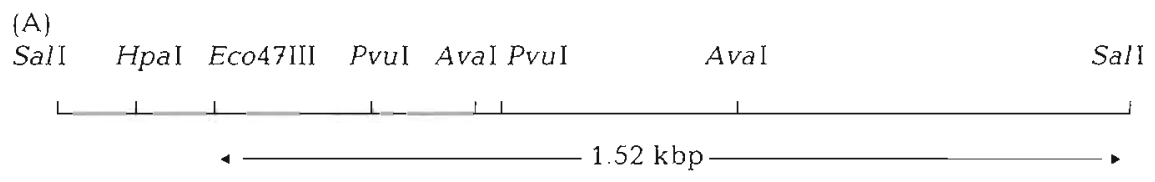

(B)

Multiple cloning site:

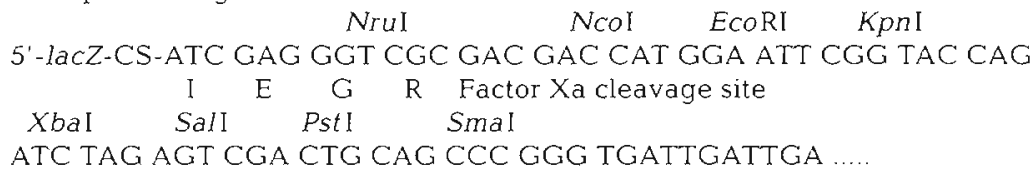

(C)

Factor Xa site R. salmoninarum gene rsh (Eco47 III/Sall fragment) lacZ-CS-ATC GAG GGT CGG CTC GCT ............. GCG CGT TAG ..

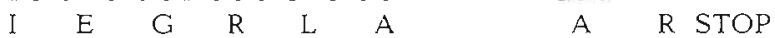

Fig. 1. Cloning strategy for the construction of a fusion of the lac $Z$ gene with gene rsh. (A) Restriction map of the $1.67 \mathrm{kbp}$ Sall fragment of Renibacterium salmoninarum DNA from which the $1.52 \mathrm{kbp}$ Eco47IIl/Sall fragment of gene rsh to be fused was excised. The initiation codon of gene rsh is located 39 nucleotides to the right of the HpaI site (Evenden 1993). (B) Restriction map of the multiple cloning site of pAX5+. The factor Xa cleavage site is shown. (C) Structure of the lacZ-rsh fusion in pAX5+ 


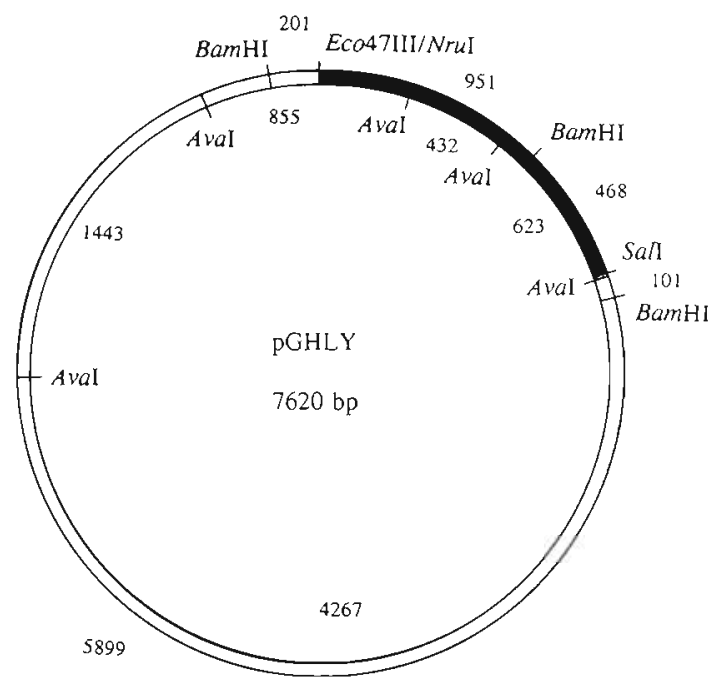

Fig. 2. Physical map deduced for pGHLY. Numbers represent base pairs between neighbouring restriction sites

ments showed that the $\beta$-galactosidase-RSH fusion protein was expressed at a high level and mainly in a soluble form. The $\beta$-galactosidase-RSH protein was purified from the cytoplasm of Escherichia coli XL1Blue by using a 1 -step affinity chromatography method. Degradation of the $\beta$-galactosidase-RSH protein was minimised by ensuring that samples, glassware, buffers and the affinity column were kept cold throughout. The purified $\beta$-galactosidase-RSH protein migrated as a single band on reduced SDS-PAGE with a calculated molecular weight of 160000 , which was close to the predicted size of 159500 (Fig. 3). Gene rsh

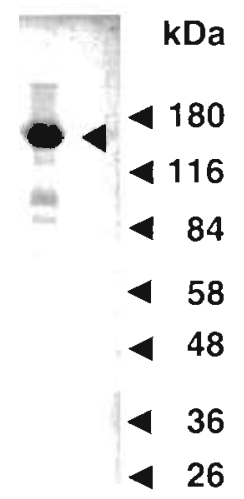

encodes a protein consisting of 416 amino acids with a molecular mass of 47600 daltons (Evenden 1993). The construction of the gene fusion would yield a truncated gene product of 381 amino acids and 43442 molecular weight fused to the $\beta$-galactosidase protein. RSH was fused to $\beta$-galactosidase starting from Leu-36 which is close to the carboxy terminal end of the putative membrane-spanning portion of RSH located at Ala-37 (Evenden 1993).

Seven strains of Renibacterium salmoninarum which have been shown to differ in their virulence by previous research (Bruno 1988, 1990) were probed with antibodies raised against the affinity purified $\beta$ galactosidase-RSH fusion protein. Cell extracts or
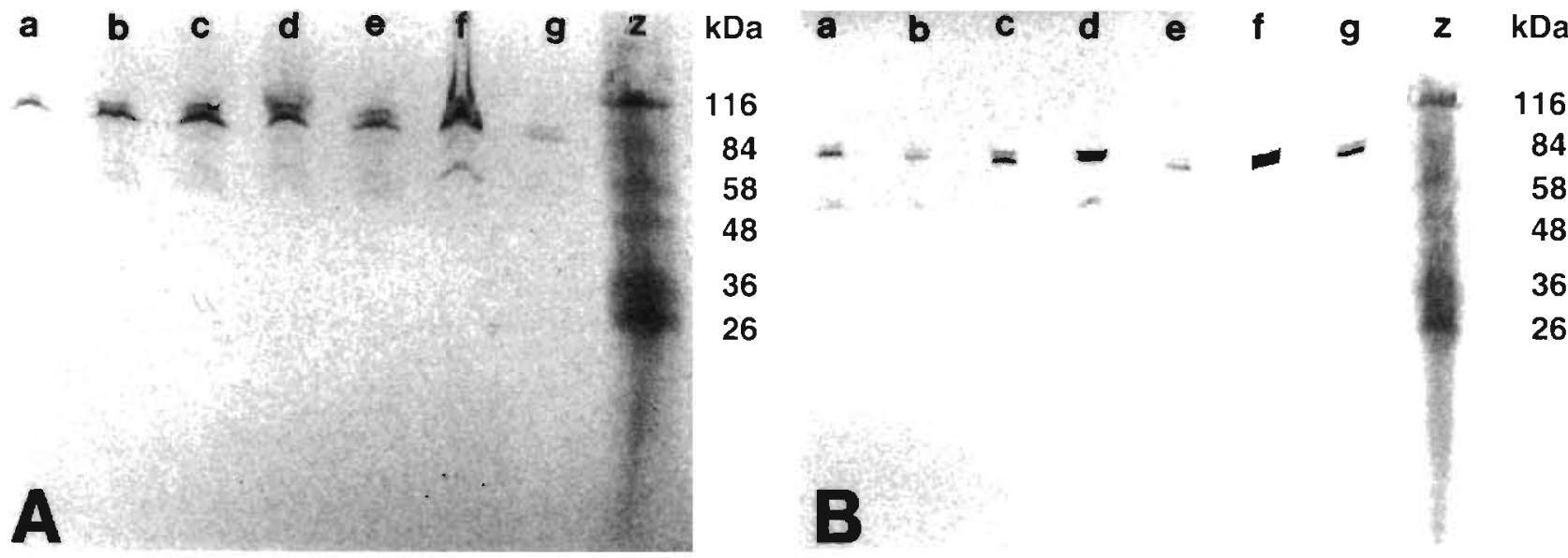

Fig. 4. Detection of epitopes of $\beta$-galactosidase-RSH in cell extracts of 7 Renibacterium salmoninarum strains. Preparations were separated by SDS-PAGE using a 10 to $15 \%$ gradient gel, transferred onto nitrocellulose, and then probed with a rat antiserum raised against $\beta$-galactosidase-RSH fusion protein. Cultures were grown in either (A) MHCB or (B) MHCB supplemented with 200 fM EDDHA. Tracks were: (a) strain 910019; (b) strain MT452; (c) strain MT425; (d) strain MT420; (e) strain MT417; (f) strain MT414; (g) strain ATCC33209; (z) protein molecular weight standards (marked in kDa) 
ECPs were isolated from cells which had been cultured under either iron-restricted or iron-sufficient conditions, separated by SDS-PAGE and blotted onto nitrocellulose. Cell extracts of all strains of $R$. salmoninarum were found to possess epitopes recognised by rat antiserum to $\beta$-galactosidase-RSH regardless of the availability of iron. Two major bands of 82000 and 78000 were found to be present together with a number of weaker bands between 78000 and 56000 and one very weak band at 25000 which is not discernible in the figure (Fig. 4A, B). No epitopes of $\beta$-galactosidase-RSH were detected on Western blots of ECPs. Evenden (1993) has predicted that the RSH protein is anchored to the cell wall and is exposed on the surface of the bacterium. This may explain the absence of detectable quantities of the protein in the ECPS. In addition, sequence analysis by Evenden (1993) has shown that the rsh gene encodes a protein of 47600 molecular weight which is smaller than many of the bands identified on Western blots in this study. Some explanations for this include the possibility that the native protein may possess carbohydrate or lipid moieties which alter its migration on SDS-PAGE. In this respect, Evenden (1993) has identified at least 3 possible carbohydrate attachment sites (Asn-X-Ser/Thr) on the $\mathrm{RSH}$ protein and the molecule is rich in proline $(8.65 \%)$, which is known to retard the migration of polypeptides on SDS-PAGE gels (Hames \& Rickwood 1990). Alternatively, other molecules produced by $R$. salmoninarum may share epitopes which are present on the $\beta$-galactosidase-RSH fusion protein. In relation to this possibility it is worth noting that $R$. salmoninarum has been shown to be negative for $\beta$-galactosidase activity (Goodfellow et al, 1985), and Western blots of $R$. salmoninarum cell extracts which were probed with mouse anti- $\beta$-galactosidase antiserum showed no evidence for the recognition of cross reactive epitopes.

Given the paucity of knowledge relating to Renibacterium salmoninarum this study represents progress towards a better understanding of the pathogen. The availability of gene $r s h$ and an antiserum directed against epitopes of the native molecule will greatly facilitate further studies of the functional significance of this protein, in particular, the immunological significance of $\mathrm{RSH}$ in the pathogenesis of $\mathrm{BKD}$. The RSH protein has been previously shown not to be recognized on Western blots probed with rabbit antiserum raised against products derived from $R$. salmoninarum cultured in vitro (Evenden 1993). The reasons for this are as yet unclear but may be related to either the immunodominance of the p57 antigen or the presence of immunosuppressive components in $R$. salmoninarum products. These questions will be addressed by future research
Acknowledgements. We thank the Scottish Salmon Growers Association for funding, SOAFD Marine Laboratory, Aberdeen, Scotland for bacterial strains, helpful advice and assistance, Dr Mary C. O'Hare, Rheumatology Research Unit Addenbrooke's Hospital, Cambridge, for kindly providing the pAX5+ vector, and Drs A. B. Wrathmell and P. J. Glynn for assistance.

\section{LITERATURE CITED}

Bruno DW (1988) The relationship between auto-agglutination, cell surface hydrophobicity and virulence of the fish pathogen Renibacterium salmoninarum. FEMS Microbiol Lett 51:135-140

Bruno DW (1990) Presence of saline extractable protein associated with virulent strains of the fish pathogen Renibacterium salmoninarum. Bull Eur Ass Fish Pathol 10:8-10

Bullen JJ, Griffiths E (1987) Iron and infection: molecular, physiological and clinical aspects. John Wiley \& Sons Chichester

Chien MS, Gilbert TL, Huang C, Landolt ML, O'Hara PJ Winton JR (1992) Molecular cloning and sequence analysis of the gene coding for the $57-\mathrm{kDa}$ major soluble antigen of the salmonid fish pathogen Renibacterium salmoninarum. FEMS Microbiol Lett 96:259-266

Evelyn TPT (1993\} Bacterial kidney disease-BKD. In: Inglis V, Roberts RJ, Bromage NR (eds) Bacterial diseases of fish Blackwell, Oxford, p 177-195

Evenden AJ (1993) The use of gene cloning techniques in the study of the fish pathogen Renibacterium salmoninarum $\mathrm{PhD}$ thesis, University of Plymouth

Evenden AJ, Gilpin ML, Munn CB (1990) The cloning and expression of a gene encoding haemolytic activity from the fish pathogen Renibacterium salmoninarum. FEMS Microbiol Lett 71:31-34

Evenden AJ, Grayson TH, Gilpin ML, Munn CB (1993) Renibacterium salmoninarum and bacterial kidney disease the unfinished jigsaw. Ann Rev Fish Dis 3:87-104

Findlay BB (1993) Molecular genetic approaches to understanding bacterial pathogenesis. In: Hormaeche $\mathrm{CE}$, Penn CW, Smyth CJ (eds) Molecular biology of bacterial infection. Cambridge University Press, Cambridge, p 33-46

Goodfellow M, Embley TM, Austin B (1985) Numerical taxonomy and emended description of Renibacterium salmoninarum. J gen Microbiol 131:2739-2752

Grayson TH, Bruno DW, Evenden AJ, Gilpin ML, Munn CB (1995b). Iron acquisition by Renibacterium salmoninarum: contribution of iron reductase. Dis aquat Org 22:157-162

Grayson TH, Evenden AJ, Gilpin ML, Martin KL, Munn CB (1995a) A gene from Renibacterium salmoninarum encoding a product which shows homology to bacterial zinc metalloproteases. Microbiology (UK) (in press)

Hames BD, Rickwood D (1990) Gel electrophoresis of proteins: a practical approach, 2nd edn. IRL Press, Oxford

Laemmli UK (1970) Cleavage of structural proteins during assembly of the head of bacteriophage T4. Nature 222 : $680-685$

Markmeyer P, Ruhlmann A, Englisch U, Cramer F (1990) The pAX plasmids: new gene-fusion vectors for sequencing, mutagenesis and expression of proteins in E. coll. Gene 93:129-134

Towbin H, Staehelin T, Gordon J (1979) Electrophoretic transfer of proteins from polyacrylamide gels to nitrocellulose sheets: procedure and some applications. Proc natl Acad Sci USA 76:4350-4354

Manuscript first received: September 13, 1994

Revised version accepted: January 22, 1995 